\title{
Slow tourism, public funding and economic development. A critical review on the case of the Way of St. James in Galicia
}

\author{
Rossella Moscarelli* \\ Politecnico di Milano, Dipartimento di Architettura e Studi Urbani (DASTU), Via Edoardo Bonardi 3, 20133 Milano, MI, Italy
}

Received: 5 March 2021 / Accepted: 30 April 2021

\begin{abstract}
The analysis of the economic dimension relating to the Way of St. James is confronted in a double reflection. On the one hand, the intention is to reconstruct the public funds that have supported the project to relaunch the Way over the years. On the other hand, we discuss one of the impacts of the route on the territory - that relating to economic development following the "second coming" of tourism. The analysis of both aspects shows rather unexpected results. In the first case it is shown how slow tourism projects can be real priority axes on which to concentrate large public funds. The second calls into question the effective ability of a path, albeit with significant tourist flows, to activate demographic recovery and to improve economic conditions. However, the need is discussed to investigate the question in greater detail which, if analyzed in the various parts, really shows the importance, not only economic, that the process of development of the Way has entailed for the territory it passes through.
\end{abstract}

Keywords

Slow tourism; territorial development; public funds.

\section{Turismo lento, financiamento público e desenvolvemento económico. Revisión crítica do caso do Camiño de Santiago en Galicia}

\section{Resumo}

A análise da dimensión económica do Camiño de Santiago afróntase nunha dobre reflexión. Por unha banda, a intención é reconstruír os fondos públicos que apoiaron o proxecto de relanzamento do Camiño ao longo dos anos. Doutra banda, coméntase un dos impactos do roteiro no territorio, o relativo ao desenvolvemento económico tras o redescubrimento turístico. A análise de ambos os aspectos proporciona resultados bastante inesperados. No primeiro caso, móstrase como os proxectos de turismo lento poden ser verdadeiros eixes prioritarios nos que concentrar grandes fondos públicos. 0 segundo cuestiona a capacidade efectiva dun camiño, aínda que con importantes fluxos turísticos, para activar unha recuperación demográfica e unha mellora das condicións económicas. Con todo, discútese a necesidade de indagar con maior atención a cuestión que, analizada nas distintas partes, mostra realmente a importancia, non só económica, que o proceso de desenvolvemento do Camiño supuxo para o territorio que atravesa.

\section{Palabras clave}

Turismo lento; desenvolvemento territorial; fondos públicos.

JEL Codes: Z32.

*Corresponding author: rossella.moscarelli@polimi.it 


\section{Introduction: investments and economic impacts along a slow tourism line}

The aim of this paper is to propose a critical review of the relationship between the tourist development of the Way of St. James and the economic growth of the territories it crosses. Such economic impacts are here correlated to the reconstruction of public investments dedicated to the tourist revival of the Way, from 1993 to present day.

The relationship between tourism and the impacts on the territory, especially those related to economic development, has been the subject of debate for years. Indeed, the economic impacts of tourism have been broadly analyzed during recent decades (Archer \& Fletcher, 1996; Fleming \& Toepper, 1990; Pablo-Romero \& Molina, 2013). According to this literature, tourism generates economic benefits. At a local level, the economic benefits are associated with both increased investments by government and commercial organizations and consumer spending in the local tourism economy. This leads to economic development through improved infrastructure (e.g. roads, water supply, energy supply) and job opportunities created responding to increased visitor spending, both directly and indirectly related to tourism. In 2002, Balaguer \& Cantavella-Jordá introduced the so-called "tourism-led growth hypothesis" (TLGH), to analyze the relation between the development of the tourism sector and the growth of the Spanish economy using econometric models. The TLGH model was widely used by several scholars, as shown in a useful overview by Brida, Cortés-Jiménez \& Pulina (2016). They apply the model to different countries in the world, aiming at demonstrating the association between economic progress and tourism development.

There are also researchers who see critical aspects related to the economic impact of tourism. Recently, Mitra (2019) has re-examined the direction of the casual relationship between tourism growth and economic progress, affirming that "the results for TLGH have proven mixed and inconclusive, and sometimes even opposing, across different studies". Moreover, Antonakakis, Dragouni \& Filis (2015) suggest that tourism is not a secure development strategy for a territory since its impacts on economic growth are time dependent, varying according to the evolution of the destinations. This confirms what Butler (1980) argued, proposing the seven stages of tourism. According to his theory, after the phases of development and consolidation of tourism in a place, there is the risk of stagnation, and even worse, of decline.

Another critical point is the nature of job opportunities that arise through tourism. Jobs may not be desirable (Lankford, 1994); they can be part-time, seasonal, low-skilled, poorly paid and with little prospect of career development (Mason, 2003). As well as questioning economic benefits, many studies identify a variety of negative economic impacts, such as localized inflation, increased house prices and housing costs, increased cost of living and increased local taxes (Hall \& Page, 2006; Mason, 2003).

Many of the aspects discussed by these authors can also be applied to the case of the Way of St. James which, on the one hand, represents a fundamental tourist resource in the Spanish national context, and especially in Galicia but which, as we will see, on the other hand, it does not seem to have such an incisive impact on the economic development of the territories it crosses.

Today, the Way of St. James represents an example of a certain type of tourism, sometimes defined as "religious" (Esteve, 2005; Pardellas, 2005; Santos, 2002) or "spiritual" (López, Lois González \& Castro Fernández, 2017; MacLaine, 2000; Tilson, 2005), sometimes as "cultural" (Fistola \& La Rocca, 2018; Lois González \& Somoza Medina, 2003; Rodríguez, 2006; Santos, 2006a), sometimes as "slow" (Lois González \& López, 2021; Moscarelli, 2021). The different meanings with which tourism activated by the Way of St. James is defined refer to the different definitions that are attributed to each tourist practice, but also to the different manners in which it is possible to interpret the experience of the Way. In this case, we intend to consider the Way as a case of slow tourism that develops along a long line, namely crossing different territories and along which is possible to travel for more days. In this sense, this analysis can be seen as a case study of the economic impact generated by a slow tourist line. The economic effects generated by slow tourism and particularly by that which develops along territorial lines have been discussed, highlighting the economic potential of this sector (Allgemeiner 
Deutscher Fahrrad-Club [ADFC], 2019; Cope, Doxford \& Hill, 1998; Downward, Lumsdon \& Weston, 2009; Dunkelbergt \& Püschel, 2009; Lumsdon, 2000; Midmore, 2000; Piket, Eijgelaar \& Peeters, 2013; Ritchie, 1998) both for the direct and indirect impacts. The assessment that is proposed in this essay hopes to be part of this literature.

Considering the Way as an example of a slow tourist line, may also change the perspective by which tourism and economic impacts may be related. Therefore, the hypothesis proposes that a certain type of tourism, that is activated along a line to slowly discover the territory (such as that of the Way), is not only an opportunity for an economic growth in itself, but for determining a different growth compared to what happens with other forms of tourism. The difference can be found in two main elements. The first concerns the distribution of effects. If traditional tourism, made up of punctual destinations rather than of travel between places, determines a concentration of economic impacts (Gössling, Hall \& Weaver, 2009), tourism activated along a line can encourage a more equitable and balanced dissemination of the benefits (Pileri, Giacomel \& Giudici, 2015). In this sense, it is possible that supporting mechanisms, intentional or not, were established between places. Let us explain better. If the suggestion of the line is also fueled by the presence of some "destination-places" - such as Leon or Santiago for the Way- the idea of reaching these places along a path also allows less iconic places scattered along the line to draw those economic benefits which, meaning the presence of the line itself, would be concentrated exclusively in the cities capable of being tourist attractions in themselves. The second element that differentiates the impact of punctual tourism from that generated along a line is the idea of a virtuous supply chain with which to involve not only the territories directly crossed, but also the surrounding ones. This can partly happen even in the case of more traditional tourism, even if the peculiarity of slow tourism must also be considered in the attitude of those who practice it wanting to go further into the places and live an authentic experience (Dickinson, Lumsdon \& Robbins, 2011; Gardner, 2009; Heitmann, Robinson \& Povey, 2011). One of the clearest examples of a supply chain is certainly that linked to agricultural production and the transformation of food, which can also take place indirectly in the places crossed by the Way.

The paper is structured as follows. The first section considers the methodology and limits of the analysis. The sources of the data and the difficulty of the calculation are then discussed. The analysis is divided into two main parts. The first concerns the reconstruction of public funding that over the years has been allocated to the development of the Way. The second part of the analysis collects the main reflections and research on the economic impacts generated by the Way. From the development of these two analyses, it is finally possible to relate the public investment for the development of the project to the economic impact that this is able to produce on the territory. It turns out that the correlation between these two aspects is not direct. This allows us to broaden the reflection on the impacts of the Way of St. James in particular, and of slow tourist lines in general, confirming the importance of investing in such projects.

\section{Material and methods}

The analysis is divided into two main parts. The first concerns the assessment of public investment that has supported the contemporary relaunch ${ }^{1}$ of the Way of St. James. The second proposes a critical review of studies and research that have reconstructed the economic impacts on the territory generated by the Way for both prospects, it is appropriate to define the method and limits of the analysis.

Starting with the former, the main source of the data is the annual funding dedicated to public companies born expressly for the development of the Way. This choice was necessary in order to

\footnotetext{
1 The contemporary revival of the Camino de Santiago in a tourist key dates back to the early nineties, when the Galician Government, with the Xacobeo 1993, promoted the first secular celebration of a Holy Jubilee Year (Celeiro, 2013; Rodríguez, 2004).
} 
isolate the investment made exclusively for it. This responds to the difficulty of separating the portion that was destined for the Way from the annual financing data of companies dedicated to tourist promotion in general. Take, for example, a publicly funded company such as Turgalicia which in its period of activity, 1992-2013, was involved in promoting tourism in Galicia and of which it is possible to reconstruct the data relating to the public funds received each year. What does not make this data reliable is the fact that Turgalicia did indeed deal with promoting the Way of St. James, but not exclusively. It cannot therefore be used as a significant database to reconstruct the investment made.

Here we find the first limit of the analysis: it only considers the case of Galicia, the only Autonomous Community which has created a public body completely dedicated to the Way of St. James.

In light of these considerations, the analysis of the funds dedicated to the Way is an original result of this paper and it was carried out considering the funding allocated each year by the Galician Government to the "S.A. de Xestión Xacobeo". This company, born as S.A. de Xestión do Plan Xacobeo 93 (Decreto 377/1991), is an anonymous society (hence the acronym S.A.), created in 1991 by the Galician Government, because of the Jacobean Year $^{2}$ of 1993. Its objective was to execute the civil initiatives of the Galician Autonomous Administration in relation to the celebration of the Holy Year, established in the Plan Xacobeo 93. Between 1992 and 1993, it executed the initiatives to recover the route of the French Way in Galicia and provided it with the initial services, among which the creation of the public network of hostels for pilgrims stands out. Since 1994, the S.A. de Xestión do Plan Xacobeo has extended the donation objectives to the other Galician Jacobean routes under the Plan Xacobeo 99, which culminated in the Holy Year of 1999. The same thing happened for the holy years of 2004 and 2010. Since its creation, this company was attached to the departments of Institutional Relations -until the end of 1993-, Culture -until 2005-, Industry and Tourism -until 2009-, and Culture and Tourism -since 2009.

To carry out the analysis, the funds allocated to S.A. Xacobeo were then reconstructed through the Annual Budget Laws of Galicia (1991-2018) ${ }^{3}$. This determines the time frame taken into consideration since the available data starts from the year of creation of the S.A. Xacobeo, that is 1991, and therefore does not allow an assessment of how much was invested before. Loans dedicated to S.A. Xacobeo include the operating costs of the company itself as well as the development of activities related to the Way -intervention on the infrastructure, network of public hostels and promotion of the Jacobean culture, which had to take place through exhibitions, publications, concerts, magazines, sport events, and so on (Celeiro, 2013). Thus, it appears how funding concerning other activities not developed by the S.A. Xacobeo is not considered. For example, it is the case of the activities linked to the tourist promotion of the Way which was managed until 2013 by Turgalicia, and, which, in any case, has contributed to the development of the project.

Moreover, considering just the S.A. Xacobeo financed by the Galician Government, other kinds of public funds, such as those from provincial and municipal administrations, are not considered. Again, this does not mean that these funds were not relevant, but just that it was not possible to find any data.

Finally, there is also another kind of problem, linked to the precise amount of investment. Many interventions have certainly favored the development of the Way, and the Way itself has been a promoter of it, but those investments cannot be counted as financing explicitly and exclusively dedicated to it. A clear example of this is the improvement interventions at the Santiago de Compostela railway station and airport (Rodríguez, 2004).

All the limits just discussed, make clear that the result obtained certainly underestimates the actual extent of public investment dedicated to the Way of St. James. Nevertheless, the analysis provides an idea of the public commitment and importance given to this project. The economic commitment with

\footnotetext{
2 The Jacobean Year is a jubilee year extended only to the city of Santiago de Compostela. It represents a real jubilee, a holy year granted in 1179 by Pope Alexander I. The Jacobean Year is celebrated every 6, 5, 6 and 11 years when the feast of St. James (July 25) coincides with a Sunday. The Jacobean Years have always been an occasion for extraordinary events and pilgrimages, attracting to Santiago thousands of pilgrims who, on that occasion, can obtain a plenary indulgence.

3 This data includes also the current operating expenses of the Company.
} 
which the Way of St. James was carried out is a key aspect with which it is also possible to measure the weight that this project has meant especially for the Galicia Region, which more than any other has financed its development.

Moving to the latter aspect, the economic impacts generated by Way represent the counterpart of the public investments made, even if the economic impact is certainly not the only one that defines a wider territorial regeneration. The study of the economic impacts that the Way of St. James has had on the places it crosses is not easy to decode, so much so that it is necessary to refer to studies that in several years of research have tried to assess the issue (Morales, 2017). It is therefore considered useful to propose a review of the main studies that have tried to attempt a correlation between the tourist development of the Way and the economic growth of the territory crossed.

Before entering into the merits of these studies, it is appropriate to define the limits that can be encountered in the calculation of the economic impacts in the case of a slow tourism line. First, as in the measurement of all impacts, it is necessary to distinguish the direct, indirect or induced impacts. In the case of a slow travel, for example, the direct impacts could be those related to the pilgrims' accommodation services, such as hostels, bars or restaurants in the places at beginning or at the end of the stage but at the same time should be considered indirect impacts which are not produced in the places which experience the actual passage of pilgrims, or induced, feeding both direct and indirect impacts. An example of indirect impacts can be the production of farms not in the municipalities through which the paths pass, but which still serve those same bars or restaurants along the way. It is easier to calculate the direct impacts rather than the others, although both are important results of the project. What is usually done in these studies is to verify the impacts on the municipalities crossed by the line. In this way, it is not said that all impacts are measured, precisely because slow ways do not only impact the territory directly affected by the passage (Figure 1).

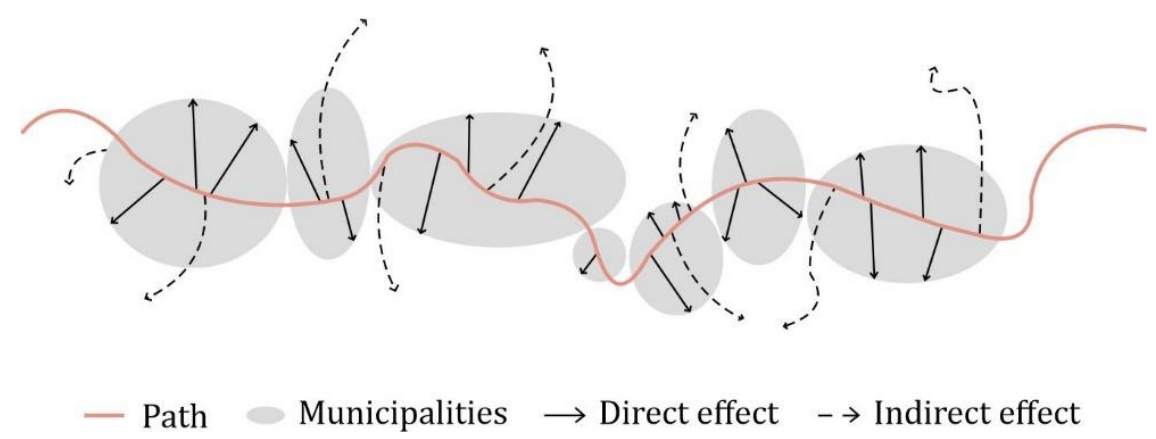

Figure 1. A limit in calculating the economic impacts of a path: the presence of direct and indirect effect. Source: own elaboration.

The second limit concerns the scale at which direct impacts are usually assessed, i.e. the municipal scale. In the case of a path travelled mostly on foot, this can be incorrect or in any case, can lead to relevant inaccuracies. In fact, it has been calculated that the direct effects of a walking traveler on a territory is very concentrated, almost as if defining a tunnel through which the pilgrim moves, i.e. within 200/300 $\mathrm{m}$ from the line of the path (Fernández-Fernández, Lazovski \& Real Neri, 2020). This means that even the data on the municipal scale is inaccurate since the direct effects will only affect the nucleus through which the path passes and not all the municipal area. This becomes even more evident in cases of very dispersed territorial conformations, as in the case of Galicia. In these cases, the municipalities are also formed by dozens of scattered hamlets in the municipal area (Figure 2). 


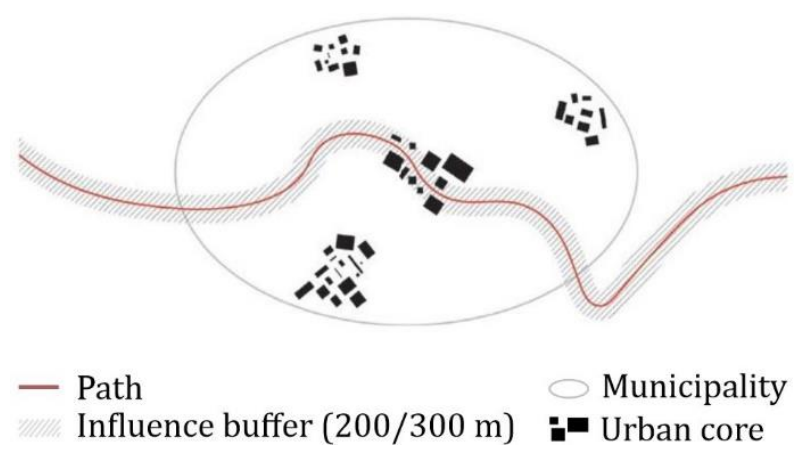

Figure 2. A limit in calculating the economic impacts of a path: the influence of the path on the territory, equal to about 200-300 $\mathrm{m}$ from the path. Source: own elaboration.

To sum up, in order to specifically evaluate the economic impacts of the ways in the territory, it would be necessary to consider them case by case and go into detail on how the route crosses the municipality. For the Way case, for example, the municipalities of Sarria and Paradela, two Galician towns crossed by the Camino, are emblematic. Sarria is a rather important center when compared to the very small mountain and exclusively rural municipalities of the area and is configured as a historic nucleus on a hill and the nucleus of the new city below. The effects of the Camino, in the case of Sarria, are concentrated almost exclusively on the historical nucleus, through which the way passes. Looking at the municipal scale, the data do not demonstrate any impressive effects since the town was flourishing economically and demographically. It can be seen how all the effects of the Way are concentrated in the historical center on the hill that, before the revitalization of the Way, was completely abandoned.

Another peculiar case is that of Paradela, a municipality through which the Way passes, but without touching any urban nucleus (in fact, it only passes through wooded areas). In this case the direct impacts on the municipal area will be of little significance since the urban centers are too far from the line the pilgrims follow.

These are just two examples -but on closer inspection each municipality has its own peculiaritieswhich show how an analysis on a municipal scale (unit of measurement that is generally chosen for the assessment of impacts) is not always suitable. Nevertheless, it is difficult to obtain a lower disaggregation of statistical data and we almost always just have data on a municipal scale. At any rate this testifies to the difficulty of returning an economic assessment of such a complex project.

\section{Results}

As for the methodology, the results of the analysis on public investments dedicated to the development of the Way and, subsequently, the critical review of the studies on the economic impacts on the territory are presented separately. In the discussion of these results, both parts of the analysis will be correlated and commented in a synoptic view.

\subsection{The economic effort of Galicia to support the Camino}

Table 1 collects all the data relating to the financing of S.A. Xacobeo.

A strong variability is noticeable in these investments, a sign of the fact that, depending on the year the company was financed, and consequently the projects on the Way, to a different degree. This is evident in the case of the Jacobean Years (in bold in the table) and is justified by the need to prepare 
the jubilee celebrations. Beyond the preparations of the Jacobean Years, the variability is very present between the different years. One of the likely explanations for this trend may also be the change in regional government. Between 1991-2005, when most was invested in the project, the government of Galicia was chaired by Manuel Fraga, the first figure to relaunch the Camino de Santiago. From 2006 to 2009 a left-wing coalition presided, while from 2010 onwards there was a return to a right-wing government. The changes in government and their interest in the project can also have affected the management of public funding in favor of the Way. The variation of the funds could also be explained by the strong economic crisis, starting in 2007, that has undoubtedly affected the budget of the S.A. Xacobeo ${ }^{4}$.

Table 1. Public funding to finance the S.A. de Xestión Xacobeo

\begin{tabular}{|c|c|c|}
\hline Years & Public funding to S.A. de Xestión Xacobeo (mln€) & Annual tax of variation \\
\hline 1991 & No data found & - \\
\hline 1992 & No data found & - \\
\hline 1993 & No data found & - \\
\hline 1994 & No data found & - \\
\hline 1995 & 24,9 & - \\
\hline 1996 & No data found & - \\
\hline 1997 & 7,3 & - \\
\hline 1998 & 25,6 & $+253 \%$ \\
\hline 1999 & 39,1 & $+53 \%$ \\
\hline 2000 & 25,0 & $-36 \%$ \\
\hline 2001 & 24,9 & $-0,4 \%$ \\
\hline 2002 & 24,7 & $-1 \%$ \\
\hline 2003 & 24,7 & - \\
\hline 2004 & 34,3 & $+39 \%$ \\
\hline 2005 & 30,7 & $-11 \%$ \\
\hline 2006 & 28,4 & $-7 \%$ \\
\hline 2007 & 27,8 & $-2 \%$ \\
\hline 2008 & 28,5 & $+2 \%$ \\
\hline 2009 & 28,4 & $-0,4 \%$ \\
\hline 2010 & 84,3 & $+197 \%$ \\
\hline 2011 & 20,7 & $-75 \%$ \\
\hline 2012 & 16,8 & $-19 \%$ \\
\hline 2013 & 11,7 & $-30 \%$ \\
\hline 2014 & 4,6 & $-61 \%$ \\
\hline 2015 & 5,0 & $+7 \%$ \\
\hline 2016 & 4,9 & $-2 \%$ \\
\hline 2017 & 4,9 & - \\
\hline 2018 & 4,8 & $-1 \%$ \\
\hline
\end{tabular}

Source: own elaboration on the base of data collected by Law of Annual Budgets of Galicia (1995-2018). In 1991, 1992, 1993, 1994 and 1996 it was not possible to find the Law and the data.

It is noted that for some years it was not possible to recover the amount of the loan to the S.A. Xacobeo. Rodríguez (2013) has reconstructed, based on what was declared in the official documents of the Galician Government (Xunta de Galicia, 1994a), the data on the funding for the development of Xacobeo 1993 between 1990 and 1993. These correspond to approximately € $126 \mathrm{~m}$, necessary for

\footnotetext{
4 This aspect, which is quite plausible to explain the reduction in financing to S.A. Xacobeo, is not found by observing the annual budget data of the Galician Government. In fact, contrary to the expectations, in the years of economic crisis, regional subsidies to various public companies, including S.A. Xacobeo, do not appear inferior compared to previous years. Instead, it appears that of the total of these loans, it was decided to allocate less funds to S.A. Xacobeo.
} 
interventions on the infrastructure of the Way (creation of a network of public hostels, interventions on the route and signs), for cultural, socio-economic and tourist promotion and for the management costs of the administrative structures created to support the project (such as S.A. Xacobeo, but not exclusively).

From the trends above discussed it is possible to note that from 2011 onwards the loans dedicated to S.A. Xacobeo radically decreased compared to the past. This can be explained by the fact that the Galician Government established the Agencia de Turismo de Galicia (Decreto 196/2012) which took on various functions that previously were in the hands of S.A. Xacobeo in 2012. The Agency, which is always constituted as a public body within the government, was created with the aim of promoting, coordinating and managing regional tourism policies. These also include the Way of St. James, with all its different routes, and the management of public hostels.

From 2013 onwards it is therefore possible to reconstruct the funding that the Galician Government decided to allocate to the Agencia (Table 2).

Table 2. Public funding to finance the Agencia de Turismo de Galicia

\begin{tabular}{lc}
\hline Years & Public funding to Agencia de Turismo de Galicia (mln€) \\
\hline 2013 & 35,9 \\
2014 & 43,2 \\
2015 & 43,0 \\
2016 & 44,0 \\
2017 & 46,4 \\
2018 & 58,1 \\
\hline
\end{tabular}

Source: own elaboration on the base of data collected by Law of Annual Budgets of Galicia (2013-2018).

However, it should be remembered that, unlike the situation for S.A. Xacobeo, neither the Agencia, nor its funding, are exclusively dedicated to the Way.

In the reconstruction of public funding interventions for the development of the Way, it is interesting to mention what has also been done by the Spanish government. It assumed the role of coordinator between the actions of the various Autonomous Communities (through the so-called Consejo Jacobeo ${ }^{5}$ ). From an economic point of view, the Spanish Government was involved, above all, with special tax exemption programs for private companies that decided to invest in the promotion of the Way or in sponsoring and subsidizing activities related to the celebration of the various Jacobean Years (Consejo Jacobeo, 1998, 2009; Xunta de Galicia, 1994b). The latest tax exemption program ${ }^{6}$ refers to the Xacobeo 2010, declared by the Spanish Government an event of "exceptional public interest" (Ley 2/2008, de 23 de diciembre, de Presupuestos Generales del Estado para el año 2009). The national tax benefit program aimed to promote, as in previous Jacobean Years, the sponsorship and involvement of private companies in the celebration of Xacobeo 2010. The duration of the exemption program was two years, with reference to the years 2009 and 2010. The result of this policy, promoted by the Spanish Government, was that, between 2009 and 2010, 32 companies and groups of companies participated in this program of exemptions and had allocated funds to promote

\footnotetext{
5 The Consejo Jacobeo, Jacobean Council, is an inter-administrative body for the promotion of the Way of St. James in Spain. It was created in 1992 by central government and the autonomous communities of the French and Northern Ways. This body was launched to coordinate joint initiatives aimed at promoting these itineraries in Spanish territory. The members of the Jacobean Council -ministers, councilors and senior officials of the different administrations- seek to establish coordinated plans in terms of promotion -especially when Jacobean Years approach- tourism, culture and heritage. The Council also coordinates, through the corresponding ministry of the central government, tax benefits for public and private investments linked to the promotion of Jacobean routes and culture.

${ }^{6}$ The one in progress for the celebration of Xacobeo 2021 is not considered as it is not yet possible to establish its results.
} 
the Xacobeo 2010 for more than $€ 166 \mathrm{~m}$ (Consejo Jacobeo, 2011). Once again, such data is just an estimate of the investments made for the Way. In this case, it is an estimation of private funds promoted by public policies, but also allows us to realize the importance of the project on a national scale.

\subsection{Assessing the effectiveness of investment}

The objectives with which the relaunch of the Way of St. James was financed and supported include the regeneration, also from an economic point of view, of the territories through which the line passes (Xunta de Galicia, 1994a). Xosé Santos, geographer of the University of Santiago de Compostela, is one of the first researchers to highlight the critical issues related to the impact of the Way on the territory. In his famous article, "Mitos y realidad del Xacobeo" (Santos, 1999), the lack of capacity of the Way to decisively revitalize the areas crossed is questioned. The Way is described as a key project for Galicia, for its image and recognition in Europe and worldwide, but at the same time, the analyses made to try to reconstruct the impact on the territory seem to say that it is not enough to revive more fragile areas suffering demographic and economic decline.

After this paper, other studies were carried out in order to assess the capacity of the Way to economically revitalize the territory involved in the project. Most studies, except the research by Porcal, Díez Angulo \& Iñíguez de Heredia (2012), consider only the Galician context, namely the region with the most investment and where the tourist flow is more relevant.

According to Andrade Suárez, Leira Landeira \& Caramés Valo (2010), although the number of tourists is very high, it is the characteristics of a pilgrim, or a tourist who makes a journey on foot, that do not increase the economic development of the areas crossed. Meanwhile, due to the presence of a network of public hostels (in the early years at no cost and today at an extremely low rate compared to normal tourist overnight prices). There is also a scarce propensity on the part of the pilgrim to buy products, both because they do not want to weigh down the backpack (and for this reason it would be enough to imagine a purchase with online shipments), and because the very spirit of the journey does not propose consumption. Finally, those who undertake the Camino have, as their final destination, Santiago, and therefore the stay in each stage is limited to a single night which is not enough to activate relevant economies. This situation covers the rural areas along the Camino, but not the city of Santiago on which different studies are quite in agreement in recognizing the strong economic impact on the city generated by the Way (Precedo, Revilla Bonín \& Míguez Iglesias, 2007; Santos, 2006b).

Much of this research concerning the effects of the Way on the territory uses demographic variation as one of the first indicators to assess it. The demographic decline, which also strongly involved the municipalities that benefit from and are supported by the passage of thousands and thousands of pilgrims every year, is one of the macroscopic clues with which the benefits of the Way are discussed (Andrade, 2011; Andrade Suárez et al., 2010; Precedo et al., 2007; Santos, 2006b; Santos \& López, 2018). This demographic decrease, is shown here by the rate of population variation in the ten years between 2008 and 2018, in the Spanish municipalities crossed by the French Way - the most frequented stretch and from which the recovery and reactivation projects started (Figure 3; Table 3).

What emerges is that despite being crossed by such an important line, most of the municipalities, over $75 \%$, are characterized by a negative demographic trend. The most serious situations are found in small municipalities: those with a population of less than 500 inhabitants reach an average rate of change of $-17 \%$, while those with a population between 500 and 5000 , reach an equivalent to $-12 \%$ (Table 4). It is also significant that even the Galician municipalities, which, more than others, should be affected beneficially, are characterized negatively, except for the municipality of Santiago.

In contrast to this research, there is a recent study on socio-economic impact conducted by the economists Fernández \& Riveiro (2018a), also discussed by Martínez, Castro \& Fraiz (2018). The results of this study, supported by the Galician Government, are based both on the analysis of statistical data on a municipal scale, and on field work, carried out by inspections and interviews, in two Galician municipalities along the French Way, Melide and Piedrafita do Cebreiro. 


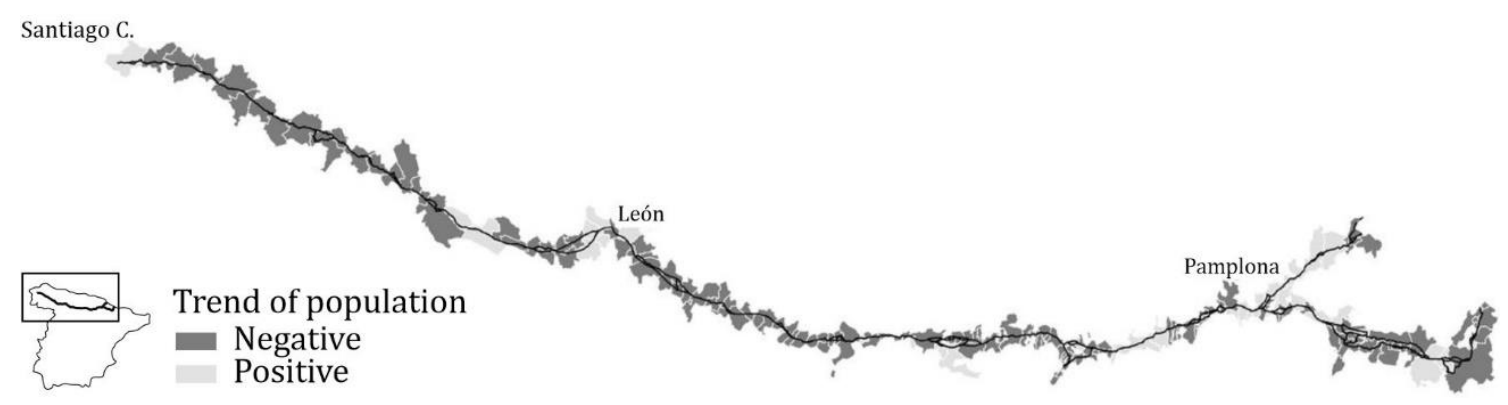

Figure 3. Demographic variation of the municipalities along the Camino (2008-2018). Source: own elaboration on the base of data INE (2008-2018).

Table 3. Demographic variation of municipalities along the Camino (2008-2018), considering the different demographic dimension

\begin{tabular}{lcccccc}
\hline Municipalities & $\# \quad$ \% on the total & $\begin{array}{c}\text { \# negative } \\
\text { trend of } \\
\text { population }\end{array}$ & $\begin{array}{c}\text { Average rate } \\
\text { of negative } \\
\text { trend }\end{array}$ & $\begin{array}{c}\text { \# positive } \\
\text { trend of } \\
\text { population }\end{array}$ & $\begin{array}{c}\text { Average rate of } \\
\text { positive trend }\end{array}$ \\
\hline Pop $<500$ inh. & 103 & $56 \%$ & 83 & $-17 \%$ & 20 & $+16 \%$ \\
$5,000<$ Pop $>500$ inh. & 59 & $32 \%$ & 39 & $-12 \%$ & 20 & $+17 \%$ \\
$10,000<$ Pop $>5,000$ inh. & 8 & $4 \%$ & 5 & $-6 \%$ & 3 & $+26 \%$ \\
Pop $>10,000$ inh. & 14 & $8 \%$ & 8 & $-4 \%$ & 6 & $+3 \%$ \\
Tot. & 184 & $100 \%$ & 135 & $/$ & 49 & $/$ \\
\hline
\end{tabular}

Source: own elaboration on the base of data INE (2008-2018).

Also in this case, the authors start from the observation of a negative demographic variation of the municipal population. This first analysis is however deepened through the so-called "demographic impact analysis". The Galician municipalities crossed by the French Way are compared with municipalities through which the Way does not pass, but which for a series of demographic and physical variables calculated in the period 1991-2001 through a compound indicator developed by the authors, can be defined as "nearest neighbors". The "nearest neighbors" are the municipalities that have the greatest similarities with the municipality of reference along the Way. Thus, it was possible to imagine what kind of demographic trend the municipalities along the Way would have had if they had followed the trend of their "nearest neighbors". The result is that the real trend is always better (except in the case of the municipality of Monterroso) than that experienced by similar municipalities in the same period. Therefore, the absolute data is contextualized by inserting it into a more general demographic situation, which, in Galicia, with the only exceptions of the main cities and coasts, is so critical that it is defined as "catastrophic" (Pazo \& Moragón 2018).

In addition to the demographic dimension, Fernández \& Riveiro carry out analyses on the economic impact that show how this is quantitatively modest (pilgrims directly represent only $2.3 \%$ of tourist spending in Galicia), but qualitatively high. One of the most interesting analysis is based on the socalled "employment multiplier", that is the number of jobs generated directly, indirectly and induced, with an increase of one million euros in the visitor's final demand. The result is that each euro spent by a pilgrim generates up to $18 \%$ more jobs than the expenditure of another type of tourist. In fact, most of the pilgrims' consumption is made up of goods and services that generate more jobs (direct and indirect). For example, the costs for food represent $61 \%$ of the expense of a pilgrim, while for a tourist they represent only 26\%. Moreover, the pilgrim shows a preference for local produce and this generates work locally, activating those virtuous supply chain processes discussed at the beginning. The tourist then spends a large part on transport (about $23 \%$ of the total cost of the trip), a sector that 
has a low multiplier effect on the local scale. This expense, on the contrary, is almost nil in the case of the pilgrim, excluding the cost to get to the Way and start the journey on foot or by bike.

What emerges from the analysis, however, is that on average, in the municipalities the French Way, passes through there is no economic activity (local production units) in $60 \%$ of the production sectors. Therefore, the indirect and induced impacts occur mainly outside the municipality on which it is not possible to apply immediate methods of analysis. In the analysis on the municipal scale, the attention therefore shifts to the assessment of the direct impact. The main direct impact on a local scale refers to the expense associated with pilgrims during their trip regarding the main services they need: restaurants, bars, hotels, guesthouses, food outlets, sporting goods or local products shops, shipping services, luggage and private transport (such as taxis), pharmacies, medical facilities, and banks. It is interesting to note that many of the services created or kept alive by the presence of pilgrims also represent services for residents. This aspect should not be underestimated especially if we consider the smaller and less densely populated urban areas, where one of the risks of demographic decline is the gradual disappearance of services (Fernández \& Riveiro, 2018b).

In addition to a quantitative analysis, it is however also appropriate to consider a qualitative assessment of the perception of who lives in those places and empirically perceives the importance of the Way in the local economy. In this regard, Fernández \& Riveiro carry out a field survey using interviews and questionnaires. In both the municipalities analyzed, Pedrafita do Cebreiro and Melide, the residents perceive important economic impacts deriving from the Way. In the case of Pedrafita it is perceived as the main economic activity of the municipality.

\section{Discussion and conclusions}

The paper proposes a reflection on the economic impacts generated by the Way of St. James, chosen, for its importance and for its success in terms of tourist flow, as a case study of a slow tourist line. Thus, the outcome of this analysis is inserted within the international debate on the theme of slow tourism and territorial regeneration. Let us retrace the development of the analysis in order to highlight its main results.

Firstly, a literature review is presented in order to discuss the relationship between tourism and economic impacts on the territory. There are two contrasting visions that emerge: the former which sees tourism as an important economic development lever and the latter, which, instead, finds the presence of numerous negative impacts related to tourism, which also reduce any economic growth that this sector may produce. Slow tourism, of which the Way is considered an example, presents many reflections with respect to the economic impacts it can produce, although neither is it unrelated to negative impacts such as the massification and loss of authenticity of the places involved in the phenomenon (Martín-Duque, 2017).

The analysis of the case of the Way of St. James seems to confirm a certain ambivalence in the interpretation of the economic impacts on the territory. Existing studies indicate that the route has a slight economic impact on the municipalities through which it passes, mainly due to the low average expenditure recorded per walker per day -around $€ 30$ according to Martín-Duque (2017). Likewise, they point out that the Way has not changed the demographic dynamics of these municipalities (Santos, 1999, 2006b) and does not manage to change the dynamics of the small populations that it is comprised of (Precedo et al., 2007). Despite this, some development is observed in the city of Santiago (Precedo et al., 2007; Santos, 2006b). However, this research is refuted by the study by Fernández \& Riveiro (2018a) which looks at the Galician municipalities the French Way transverses in relation to similar municipalities (defined as "nearest neighbors"). The importance of the Way for local economies is demonstrated in relation to what has happened in the nearest neighbors.

These results must be read with the awareness of the limits concerning the assessment of the economic impacts of a slow tourist line on the territory. In fact, all the considered studies propose an 
assessment of direct impacts, calculated on a municipal scale. In the methodology of the study it was widely discussed how it is fundamental to consider indirect and inducted impacts (also discussed in the study by Fernández \& Riveiro) and how the municipal scale, especially in some territorial contexts such as that of Galicia, fails to provide an accurate picture of direct impacts.

Such critical review of the studies on the economic impacts of the Way are read in relation to the assessment of public investments dedicated to the development of the project. This assessment has multiple limits, described in the methodology, due to the difficulty of isolating the actions and funding dedicated exclusively to the Way. For this reason, the analysis proposed in the paper is based only on the reconstruction of the funds for the S.A. Xacobeo, a public company created in 1991 by the Galician government to manage the development of the Way, its infrastructural implementation and cultural promotion.

Two results emerge from this second analysis. The first concerns the constancy of funding which, despite seeing peaks corresponding to the Jacobean Years, has never stopped since 1991. This testifies a process, a gradual and continuous construction, which did not end after a first phase of activation. The second outcome concerns the total funding dedicated to the operation of the S.A. Xacobeo which partially restores the importance of the project to relaunch the Way. From 1991 to today, $€ 532 \mathrm{~m}$ has been allocated (Law of Annual Budgets of the Autonomous Community of Galicia 1995-2018), in addition to $€ 125.6 \mathrm{~m}$ for the preparation of Xacobeo 1993 (Xunta de Galicia, 1994a). Considering the underestimation of these data, it is clear what relevance this project had for Galicia and how decisively it was decided to invest in it. Such public commitment is explained by the fact that the financing of the Way has never solely been about the infrastructure, but rather a wider and more complex territorial regeneration. Indeed, thanks to the impetus given by the celebrations of the Jacobean Years which made Galicia important nationally and internationally, public funds were invested in urban and architectural redevelopment programs, cultural and sports programs, territorial and urban planning (Xunta de Galicia, 1994a, 2000, 2004, 2005, 2011).

Once the results of both analyses have been discussed separately, it is necessary to reflect on the relationship between public investment in the Way of St. James and its economic effects generated on the territory, particularly regarding the case of Galicia. This reasoning almost seems to suggest the presence or in any case the search for a cause-effect relationship between what is invested and what is produced in the territory. This may be partly true, as it can divert attention to the broad vision that a project such as a slow tourism line must promote. The studies presented on the economic impacts generated by the Way of St. James in the areas concerned, in fact, demonstrate this. They look for indicators that in some way return the value that this project has for the territory. As we have seen, these indicators do not always tell us of an economic return, at least if we consider only the microeconomics of the places. It is interesting to compare the data relating to the demographic trend or to the expense of the pilgrim (which, in many cases, do not seem to satisfy certain development expectations) and the perception of the inhabitants who see the Way as a key element of their municipality and, more widely, of their territory (Fernández \& Riveiro, 2018a). This asymmetry can suggest that the value and importance of a project like this does not end in economic assessment or even less in an exclusively microeconomic one such as those shown. For instance, among other relevant impacts, those on landscape conservation, on heritage activation, on the recovery of the symbolic elements along the Way should be quoted.

Nevertheless, there is no macroeconomic assessment that frames the benefits, or possibly the negative aspects, generated by a project of a slow tourism line in a broader vision. From a macroeconomic point of view, the hypothesis of a supply chain, namely of those indirect or induced impacts should be verified, which extend the benefits of the passage of pilgrims to not only the places directly touched by the line. This is also fundamental because, as we have seen, lines along which one travels on foot can generate direct impacts within a rather limited band of territory. From this point of view, the indicator described by Fernández \& Riveiro (2018a) of "employment multiplier" reflects this ability of the pilgrim to activate an economy made up of a supply chain rather than of a punctual 
consumption. In this distributional dimension of benefits there is also an interesting ability to reduce the disparities that are created in any case between the places that are directly involved in the line project and those that do not enjoy direct impacts.

In conclusion, we can answer our basic question: if it is true that tourism represents a strategy of economic development, in what sense does slow tourism, activated along a line, contribute to territorial regeneration?

Firstly, a deduction based on literature reviews on the Way of St. James, leads us to say that slow tourist lines do not seem so decisive in reversing the negative trends, for example relating to demographics, of territories that present conditions of "fragility". The value to be traced, however, should not be sought exclusively in direct economic growth which does not seem to keep pace with the consumption of a "traditional" tourist, different in practices and habits from the traveller who moves slowly around the territory. It is therefore necessary to elaborate studies and research that are also able to consider the indirect or induced impacts that slow tourism can generate. This is a complex assessment, which requires precise and specific observations.

A further deduction was gleaned while researching the case of the Way St. James in particular, and on slow tourism in general (Moscarelli, 2021; Pileri \& Moscarelli, 2021). The value of a slow and, above all, of a linear tourism project should not be sought in an exclusive economic dimension, which nevertheless remains important and relevant, especially if we consider the distribution potential and activate virtuous supply chains that the paths can generate. There are also other equally significant impacts that line projects can contribute to activating. In the project of a slow tourist line there are public values that must be assessed beyond a narrow economic return. Such values are quite difficult to quantify, even if they are of fundamental importance. We are speaking of identity values, which allow small and dispersed municipalities to feel part of a large and international system. Of social values for which an otherwise impossible exchange takes place in marginal areas between pilgrims from all over the world and local people, cultural values for which a project like this ,also becomes a tool for educating citizens about the beauty of places. These, and other values, are certainly desirable effects that determine the success of the public investment made in the past and which is continuing to be made. Having made a specific focus on purely economic aspects must not make us lose sight of the depth of these projects and their value which is reflected not only in the jobs or the economic induct generated, but also in the quality of the experience that is made usable to any citizen. Moreover, there are also other equally significant impacts that a slow tourist line can contribute to activating, such as those linked to the redefinition of territorial planning and to the cooperation between places and local bodies of administration and management (Moscarelli, 2021).

By assessing these impacts, scarcely explored and rarely recognized, the importance of an innovative design approach such as that proposed by a slow tourist line is determined.

\section{References}

ADFC (2019). Travelbike Bicycle Travel Analysis - Summary report. Berlin, Germany: Allgemeiner Deutscher Fahrrad-Club. Retrieved from:

https://www.adfc.de/\%20leadmin/\%20user upload/Expertenbereich/Touristik und \%20Hotellerie/Radrei seanalyse/Downloads/Datenblatt \%20Radreiseanalyse2019 en - neu.pdf

Andrade, M. J. (2011). Consideraciones generales sobre la potencialidad del turismo para el desenvolvimiento rural: el Camino de Santiago como estudio de caso. Revista de Investigación en Turismo y Desarrollo Local, 4(9), 1-32. Retrieved from: https://www.eumed.net/rev/turydes/09/mjas.htm

Andrade Suárez, M. J., Leira Landeira, G., \& Caramés Valo, R. (2010). El turismo como factor estratégico de desarrollo rural: el Camino de Santiago Francés. Revista de Ocio y Turismo, 3, 49-82. DOI: https://doi.org/10.17979/rotur.2010.3.1.1244

Antonakakis, N., Dragouni, M., \& Filis, G. (2015). How strong is the linkage between tourism and economic growth in Europe? Economic Modelling, 44, 142-155. DOI: https://doi.org/10.1016/i.econmod.2014.10.018 
Archer, B., \& Fletcher, J. (1996). The economic impact of tourism in the Seychelles. Annals of Tourism Research, 23(1), 32-47. DOI: https://doi.org/10.1016/0160-7383(95)00041-0

Balaguer, J., \& Cantavella-Jordá, M. (2002). Tourism as a long-run economic growth factor: The Spanish case. Applied Economics, 34(7), 877-888. DOI: https://doi.org/10.1080/00036840110058923

Brida, J. G., Cortés-Jiménez, I., \& Pulina, M. (2016). Has the tourism-led growth hypothesis been validated? A literature review. Current Issues in Tourism, 19(5), 394-430. DOI: https://doi.org/10.1080/13683500.2013.868414

Butler, R. W. (1980). The concept of a tourist area cycle of evolution: Implications for management resources. Canadian Geographer, 24, 5-12. DOI: https://doi.org/10.1111/j.1541-0064.1980.tb00970.x

Celeiro, L. (2013). Xacobeo 93, el renacer del Camino. In S. Novello, F. Martínez Roget, P. Murias Fernández \& J. C. de Miguel Domínguez (Eds.), Xacobeo, de un recurso a un evento turístico global (pp. 47-64). Santiago de Compostela: Andavira.

Consejo Jacobeo. (1998). Informe de las actuaciones de la Administración General del Estado para el Año Santo Jacobeo 1999. Madrid: Ministerio de Educación, Cultura y Deporte.

Retrieved from: https://www.culturaydeporte.gob.es/consejo-jacobeo/anos- santos-jacobeos/1999.html

Consejo Jacobeo. (2009). Manual de procedimiento para el reconocimiento de los beneficios sociales. Madrid: Ministerio de Educación, Cultura y Deporte.

Consejo Jacobeo. (2011). Memoria conjunta de actividades del Año Santo Xacobeo 2010. Madrid: Ministerio de Educación, Cultura y Deporte. Retrieved from: https://es.calameo.com/read/00007533507a4e5a6427a

Cope, M., Doxford, D., \& Hill, T. (1998). Monitoring tourism on the UK's first long-distance cycle route. Journal of Sustainable Tourism, 6(3), 210-223. DOI: https://doi.org/10.1080/09669589808667312

Decreto 377/1991, de 19 de setembro, polo que se crea a S. A. de Xestión do Plan Xacobeo 93. Diario Oficial de Galicia, Núm. 218, de 11/11/1993. Santiago de Compostela: Consellería de Economía e Facenda.

Decreto 196/2012, de 27 de setembro, polo que se crea a Axencia de Turismo de Galicia e se aproban os seus estatutos. Diario Oficial de Galicia, Núm. 193, de 09/10/2021, 38646-38695. Santiago de Compostela: Consellería de Presidencia, Administracións Públicas e Xustiza.

Retrieved from: https://www.xunta.gal/dog/Publicados/2012/20121009/AnuncioC3C1-0410120003 es.pdf

Dickinson, J. E., Lumsdon, L. M., \& Robbins, D. (2011). Slow travel: Issues for tourism and climate change. Journal of Sustainable Tourism, 19(3), 281-300. DOI: https://doi.org/10.1080/09669582.2010.524704

Downward, P., Lumsdon, L., \& Weston, R. (2009). Visitor expenditure: The case of cycle recreation and tourism. Journal of Sport and Tourism, 14(1), 25-42. DOI: https://doi.org/10.1080/14775080902847397

Dunkelbergt, D., \& Püschel, R. (Eds.). (2009). Grundlagenuntersuchung Fahrradtourismus in Deutschland. Berlin, Germany: Bundesministerium für Wirtscha und Technologie.

Retrieved from: https://digital.zlb.de/viewer/resolver?urn=urn:nbn:de:kobv:109-opus-259062

Esteve, R. (2005). Turismo y religión. El impacto económico del turismo religioso; especial referencia al turismo jacobeo. In X. X. Pardellas (Ed.), Turismo religioso: o Camiño de Santiago (pp. 137-156). Vigo: Universidade de Vigo, Servizo de Publicacións.

Fernández-Fernández, M., Lazovski, O., \& Real Neri, G. (2020). Tourism impacts in an emerging destiny through the local entrepreneurship perception: The Fisterras case. Journal of Tourism and Heritage Research, 3(2), 269-285. Retrieved from: http://www.jthr.es/index.php/journal/article/view/175

Fernández, M., \& Riveiro, D. (2018a). Estudio del impacto socioeconómico del Camino de Santiago. Santiago de Compostela: Turgalicia.

Fernández, M., \& Riveiro, D. (2018b). A exclusion territorial como unha forma de manifestación dos procesos de exclusión social. SÉMATA, Ciencias Sociais e Humanidades, 30, 145-165.

DOI: https://doi.org/10.15304/S.30.5388

Fistola, R., \& La Rocca, R. A. (2018). Slow mobility and cultural tourism. Walking on historical paths. In R. Papa, R. Fistola \& C. Gargiulo (Eds.), Smart planning: Sustainability and mobility in the age of change. Green energy and technology (pp. 301-322). Cham, Germany: Springer. DOI: https://doi.org/10.1007/978-3-319-77682-8 18

Fleming, W. R., \& Toepper, L. (1990). Economic impact studies: Relating the positive and negative impacts to tourism development. Journal of Travel Research, 29(1), 35-42.

DOI: https://doi.org/10.1177/004728759002900108

Gardner, N. (2009). A manifesto for slow travel. Hidden Europe Magazine, 25, 10-14. Retrieved from: https://www.hiddeneurope.eu/a-manifesto-for-slow-travel 
Gössling, S., Hall, C. M., \& Weaver, D. (Eds.). (2009). Sustainable tourism futures, perspectives on systems, restructuring and innovations. London, UK: Routledge.

Hall, C. M., \& Page, S. J. (2006). The geography of tourism and recreation: Environment, place and space. London, UK: Routledge.

Heitmann, S., Robinson, P., \& Pove, G. (2011). Slow food, slow cities and slow tourism. In P. Robinson, S. Heitmann \& P. Dieke (Eds.), Research themes for tourism (pp. 114-127). Wallingford, UK: CAB International.

INE. (2008-2018). Cifras de población y censos demográficos. Madrid: Instituto Nacional de Estadística. Retrieved from: https://www.ine.es/dyngs/INEbase/es/categoria.htm?c=Estadistica P\&cid=1254735572981

Lankford, S. V. (1994). Attitudes and perceptions toward tourism and rural regional development. Journal of Travel Research, 32(3), 35-43. DOI: https://doi.org/10.1177/004728759403200306

Ley 2/2008, de 23 de diciembre, de Presupuestos Generales del Estado para el año 2009. Boletín Oficial del Estado, núm. 309, de 24 de diciembre de 2008, 51773-51897.

Retrieved from: https://www.boe.es/buscar/doc.php?id=BOE-A-2008-20744

Lois González, R. C., \& López, L. (2021). The singularity of the Camino de Santiago as a contemporary tourism Case. In P. Pileri \& R. Moscarelli (Eds.), Cycling \& walking for regional development. How slowness regenerates marginal areas (pp. 221-234). Cham, Germany: Springer.

Lois González, R. C., \& Somoza Medina, J. (2003). Cultural tourism and urban management in northwestern Spain: The pilgrimage to Santiago de Compostela. Tourism Geographies, 5(4), 446-460. DOI: https://doi.org/10.1080/1461668032000129164

López, L., Lois González, R. C., \& Castro Fernández, B. M. (2017). Spiritual tourism on the way of Saint James the current situation. Tourism Management Perspectives, 24, 225-234.

DOI: https://doi.org/10.1016/j.tmp.2017.07.015

Lumsdon, L. (2000). Transport and tourism: Cycle tourism - A model for sustainable development? Journal of Sustainable Tourism, 8(5), 361-377. DOI: https://doi.org/10.1080/09669580008667373

Martín-Duque, C. (2017). Los impactos del turismo en el Camino de Santiago Francés: una aproximación cualitativa. Revista de Ciencias Sociales, 5(1), 62-73. DOI: https://doi.org/10.17502/m.rcs.v5i1.155

Martínez, F., Castro, M. N., \& Fraiz, J. A. (2018). 0 turismo como fonte de riqueza en Galicia: análise dalgunhas experiencias. Revista Galega de Economía, 27(3), 65-80. DOI: https://doi.org/10.15304/rge.27.3.5437

Mason, P. (2003). Tourism impacts, planning and management. Oxford, UK: Butterworth-Heinemann.

MacLaine, S. (2000). The Camino: A journey of the spirit. New York, NY: Pocket Books.

Midmore, P. (2000). The economic value of walking in Wales: An independent report produced for the Ramblers' Association in Wales. Wrexham, UK: Ramblers' Association.

Mitra, S. K. (2019). Is tourism-led growth hypothesis still valid? International Journal of Tourism Research, 21, 615-624. DOI: https://doi.org/10.1002/jtr.2285

Morales, X. A. (2017). Las rutas culturales como factor para el desarollo de las areas rural. (Ph. D. Thesis). Santiago de Compostela: Universidad de Santiago de Compostela.

Moscarelli, R. (2021). Il turismo lento come occasione di pianificazione territoriale e di rinnovamento urbano. Il caso del Cammino di Santiago. Archivio di Studi Urbani e Regionali, 129, 125-174. DOI: https://doi.org/10.3280/ASUR2020-129007

Pablo-Romero, M. P., \& Molina, J. A. (2013). Tourism and economic growth: A review of empirical literature. Tourism Management Perspectives, 8, 28-41. D0I: https://doi.org/10.1016/j.tmp.2013.05.006

Pardellas, X. X. (Ed.). (2005). Turismo religioso: o Camiño de Santiago. Vigo: Universidade de Vigo, Servizo de Publicacións.

Pazo, A. J., \& Moragón, M. P. (2018) El despoblamiento en Galicia: la visualización de la "catástrofe". Ager: Revista de Estudios sobre Despoblación y Desarrollo Rural, 24,123-154. DOI: https://doi.org/10.4422/ager.2018.02

Piket, P., Eijgelaar, E., \& Peeters, P. (2013). European cycle tourism: A tool for sustainable regional rural development. Applied Studies in Agribusiness and Commerce, 7(2-3), 115-119. DOI: https://doi.org/10.19041/Apstract/2013/2-3/19

Pileri, P., Giacomel, A., \& Giudici, D. (2015). VENTO. La rivoluzione leggera a colpi di pedali e paesaggio. Mantova, Italia: Corraini.

Pileri, P., \& Moscarelli, R. (Eds.). (2021). Cycling \& walking for regional development. How slowness regenerates marginal areas. Cham, Germany: Springer.

Porcal, M. C., Díez Angulo, A., \& Iñíguez de Heredia, J. J. (2012). Dimensión territorial y turística de la Ruta Norte del Camino de Santiago en el País Vasco: distintas concepciones, valoraciones y propuestas de intervención sobre un fenómeno multifacético. Boletín de la Asociación de Geógrafos Españoles, 58, 177-204.

DOI: https://doi.org/10.21138/bage.2064 
Precedo, A., Revilla Bonín, A., \& Míguez Iglesias, A. (2007). El turismo cultural como factor estratégico de desarrollo: el camino de Santiago. Estudios Geográficos, 68(262), 205-234. DOI: https://doi.org/10.3989/egeogr.2007.i262.11

Ritchie, B. W. (1998). Bicycle tourism in the South Island of New Zealand: Planning and management issues. Tourism Management, 19(6), 567-582. DOI: https://doi.org/10.1016/S0261-5177(98)00063-6

Rodríguez, M. (2004). Los años santos compostelanos del siglo XX. Santiago de Compostela: Xunta de Galicia.

Rodríguez, M. M. (2013). La planificación y creación del evento Xacobeo. Análisis de la identidad y la imagen. In S. Novello, F. Martínez Roget, P. Murias Fernández \& J. C. de Miguel Domínguez (Eds.), Xacobeo, de un recurso a un evento turístico global (pp. 65-87). Santiago de Compostela: Andavira.

Rodríguez, X. S. (2006). Tourism and cultural relativity in Galicia. In X. S. Rodríguez Campos \& X. M. Santos Solla (Eds.), Galicia \& Terranova \& Labrador (pp. 73-91). Santiago de Compostela: Universidade de Santiago de Compostela.

Santos, X. M. (1999). Mitos y realidades del Xacobeo. Boletín de la Asociación de Geógrafos Españoles, 28, $103-118$. Retrieved from: https://dialnet.unirioja.es/servlet/articulo?codigo=1318654

Santos, X. M. (2002). Pilgrimage and tourism at Santiago de Compostela. Tourism Recreation Research, 27(2), 41-50. DOI: https://doi.org/10.1080/02508281.2002.11081219

Santos, X. M. (2006a). El turismo cultural en Galicia. In X. S. Rodríguez Campos \& X. M. Santos Solla (Eds.), Galicia \& Terranova \& Labrador (pp. 107-125). Santiago de Compostela: Universidade de Santiago de Compostela.

Santos, X. M. (2006b). El Camino de Santiago: turistas y peregrinos hacia Compostela. Cuadernos de Turismo, 18, 135-150. Retrieved from: http://revistas.um.es/turismo/article/view/17791

Santos, X. M., \& López, L. (2018). The Way of Saint James: A driver for rural development based on the pilgrimage tourism boom. In V. Paül, J. M. Trillo Santamaría, L. M. Agrelo Janza \& J. I. Vila Vázquez (Eds.), A companion to fieldwork in rural Galicia (pp. 171-179). Santiago de Compostela: Universidade de Santiago de Compostela.

Tilson, D. J. (2005). Religious-spiritual tourism and promotional campaigning: A church state partnership for St. James and Spain. Journal of Hospitality, Marketing \& Management, 12(1), 9-40. DOI: https://doi.org/10.1300/J150v12n01 03

Xunta de Galicia. (1994a). Xacobeo 1993. Santiago de Compostela: Xunta de Galicia.

Xunta de Galicia. (1994b). Xornadas sobre calidade no Camiño de Santiago. Santiago de Compostela: Xunta de Galicia.

Xunta de Galicia. (2000). Xacobeo 1999. Santiago de Compostela: Xunta de Galicia.

Xunta de Galicia. (2004). Arquitecturas no Camiño, 1994-2004. Santiago de Compostela: Xunta de Galicia.

Xunta de Galicia. (2005). Xacobeo 2004. Santiago de Compostela: Xunta de Galicia.

Xunta de Galicia. (2011). Memoria Xacobeo 2010. Santiago de Compostela: Xunta de Galicia. 